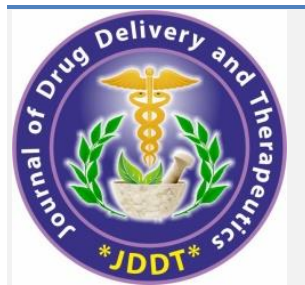

Open Access Full Text Article

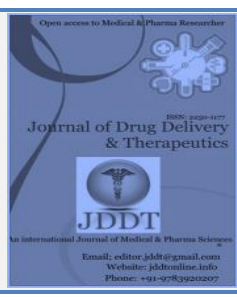

Review Article

\title{
Use of learning media to support resident doctor skills in obstetrics and gynecology during the COVID-19 pandemic: A narrative review
}

\author{
Citra Aulia Bachtiar ${ }^{1}$, Eighty Mardiyan Kurniawati ${ }^{*}$, Hermanto Tri Juwonoํㅜ Budi Utomo², Nur Anisah \\ Rahmawati $^{3}$
}

\author{
${ }^{1}$ DepartmentofObstetrics and Gynecology, Faculty of Medicine, Universitas Airlangga, Surabaya, Indonesia \\ ${ }^{2}$ Public Health-Preventive Medicine Department, Faculty of Medicine, Universitas Airlangga, Surabaya, Indonesia
}

${ }^{3}$ School of Midwifery, Universitas Airlangga, Surabaya, Indonesia

Article Info:

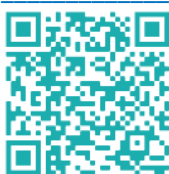

\section{Article History:}

Received 12 August 2021 Reviewed 26 September 2021 Accepted 29 September 2021 Published 15 October 2021

\section{Cite this article as:}

Bachtiar CA, Kurniawati EM, Juwono HT, Utomo B, Rahmawati NA, Use of learning media to support resident doctor skills in obstetrics and gynecology during the COVID-19 pandemic: A narrative review, Journal of Drug Delivery and Therapeutics. 2021; 11(5-S):164-166

DOI: http://dx.doi.org/10.22270/jddt.v11i5-S.5022

\section{Abstract}

COVID-19 is a pandemic that has spread in various countries. The health care system in hospitals is burdened with widespread infections and health problems. In addition, educational aspects, especially obstetrics and gynecology education, have problems in clinical practice. This study reviews the role of the learning media in supporting the competence of resident doctors in specialist education for obstetrics and gynecology. Narrative review is done by reviewing some literature that explores the use of media in supporting medical education competencies. The search was performed using $\mathrm{MeSH}$ keywords in the PubMed, Google Scholar and ScienceDirect databases. The literature used is research conducted in the last 5 years. The collected data is then arranged in a narrative manner. The challenges experienced in medical resident education, especially the focus on obstetrics and gynecology during the COVID-19 pandemic, have become a consideration for the need for innovative media so that learning can run as usual. All aspects need to ensure quality education for resident doctors because they will continue to provide health services in the future.

Keywords: Maternal health, COVID-19, Media, Obstetrics and gynecology

*Address for Correspondence:

Eighty Mardiyan Kurniawati, Urogynecology Reconstructive Division, Department of Obstetrics and Gynekology, Faculty of Medici ne, Universitas Airlangga, Dr. Soetomo Hospital, Surabaya, Indonesia, Jalan Prof dr Moestopo 6-8, Surabaya 60286, Indonesia.

\section{Introduction}

Corona Virus Disease 2019 (COVID-19) is a pandemic that has spread in 185 countries. The World Health Organization (WHO) has declared the incident a pandemic. ${ }^{1}$ Until now, exposure to this virus is still a risk in various countries, not only regarding the health system which is burdened with additional cases that are booming per day but also in various sectors, one of which is the medical education sector. Based on a UNESCO report, more than 1.5 million students in 165 countries have to lock down and not attend school or campus. This has resulted in schools, colleges and universities changing their education system into an online learning system. ${ }^{2}$ The visible impact occurs in economic changes, people's welfare, mental health, psychology, and education. $^{3}$

The corona virus disease 2019 (Covid-19) outbreak presents its own challenges for educational institutions, especially universities. The government has banned crowds, social distancing and physical distancing, wearing masks and always washing hands to fight Covid-19. The government prohibits universities from conducting face-to-face (conventional) lectures and orders them to hold lectures or online learning as delivered through the Ministry of Education and Culture. 4

Medical education, especially in the fields of obstetrics and gynecology, is having difficulty adjusting to the pandemic. The condition is a dilemma when faced with the goal of education that in the future it will produce graduates who are specialist doctors who are competent in their fields. The obstetrics and gynecology specialist education program is one of the specialist doctor education programs to produce competent obstetrics and gynecology specialists through a predetermined teaching and learning process.

In specialized medical education, namely specialists in the fields of obstetrics and gynecology, the ability to perform a cesarean section is fundamental. Cesarean section is the most frequently performed operation in obstetrics and gynecology, caesarean section is the process of childbirth or surgery through slicing the front wall of the abdomen and uterus to give birth to a fetus. 5 The increase in deliveries by cesarean section according to WHO in all countries during 2017-2018 is 110,000 per birth throughout Asia. WHO sets the standard for a country's average caesarean section is 5$15 \%$ per 1000 births in the world. ${ }^{6}$ 
This study reviews the role of the media in supporting the competence of resident doctors in specialist education for obstetrics and gynecology. This research can add insight and references for further research developments.

\section{Methods}

Narrative review is done by reviewing some literature that explores the use of media in supporting medical education competencies. The search was performed using MeSH keywords in the PubMed, Google Scholar and ScienceDirect databases. The literature used is research conducted in the last 5 years. The collected data is then arranged in a narrative manner.

\section{Results}

The Covid-19 pandemic has made it difficult for specialist medical educational institutions to continue their curriculum. There is a minimum demand for competencies that must be possessed by residents and the risk of exposure to Covid-19 in making skills that should be trained during specialist education must be set aside for the safety of students. A multicenter study in Ethiopia showed that there was a decrease in cases treated by residents during the pandemic, while most of the procedures that experienced a drastic decrease (40-80\%) were vaginal deliveries, which was $4.6 \%$, followed by cesarean section $3.8 \%$, and vaginal deliveries with tool assistance by $2.1 \%$. Meanwhile, when analyzed based on education level, residents in the first year experienced a drastic decrease in benign gynecological procedures (36\%) and gynecological oncology procedures (31\%). Residents in the second year experienced a drastic decrease in benign gynecological procedures (53\%) and gynecological oncology procedures (56\%), Residents in the third year experienced a decrease in emergency gynecological procedures $(3 \%)$, benign gynecological procedures (54\%), and gynecological oncology procedures (52\%). While the Resident in the fourth year experienced a decrease in the number of emergency gynecological procedures (2\%), benign gynecology (59\%), and gynecological oncology procedures by $50 \%{ }^{7}$

The decreasing number of actions that residents should have handled during the education program did not reduce the risk of exposure to Covid-19. A cross-sectional study in Italy on Obstetrics and Gynecology residents showed that of the 476 residents who took part in the study, $6.5 \%$ of them had Covid-19 infection from the results of nasopharyngeal PCR swabs. A total of $69.5 \%$ of Residents handle cases of confirmed Covid-19 patients. The survey results showed that there was a $54.7 \%$ decrease in case exposure compared to before the pandemic. This shows that Covid-19 has an irreversible impact on the education of specialist doctors. An innovative strategy is needed to reduce educational failure as an alternative. ${ }^{8}$ Table 1 shows the learning process and challenges during the pandemic for resident doctors.

Table 1. Learning process and challenges during the pandemic for resident doctors of obstetrics and gynecology

\begin{tabular}{|l|l|l|}
\hline No & Learning process & Challenges during a pandemic \\
\hline 1 & $\begin{array}{l}\text { Practice in hospitals and direct } \\
\text { patients }\end{array}$ & $\begin{array}{l}\text { There is a limit in the hospital for the number of patients and some non-critical } \\
\text { surgeries are postponed. Helping the handling of COVID-19 on a front liner basis } \\
\text { so that the skills for the science to be studied are reduced (Papanou, 2021) }\end{array}$ \\
\hline 2 & Practice at university laboratory & Educational laboratory to function for COVID-19 research (Quirin, 2020) \\
\hline 3 & Theory learning & $\begin{array}{l}\text { Online learning with reports of problems related to communication, student } \\
\text { assessment, use of technology tools, online experiences, anxiety related to } \\
\text { pandemics or time management stress and technophobia (Rajab, 2020) }\end{array}$ \\
\hline
\end{tabular}

Table 2 shows the prospects for using media in obstetrics and gynecology medical education. Innovation in learning is mandatory during a pandemic. The media used in previous research turned out to have a significant impact on the achievement of competency knowledge.

Table 2. media use in obstetrics and gynecology medical education

\begin{tabular}{|c|c|c|c|}
\hline No & Author, year, country & Research method & Media type \\
\hline 1 & Herlambang et al, 2020, Indonesia $^{9}$ & Experimental design & $\begin{array}{l}\text { Guide book and video about the basic } \\
\text { principles of obstetric ultrasound examination }\end{array}$ \\
\hline 2 & $\begin{array}{l}\text { Kidong Kim, et al, 2019, Korea } \\
\text { Selatan } 10\end{array}$ & $\begin{array}{l}\text { Retrospective and } \\
\text { exploratory pilot study }\end{array}$ & mobile instant messaging using Kakao Talk \\
\hline 3 & Stalcup et al, 2018, England 11 & Cross sectional & $\begin{array}{l}\text { Social media usage includes Facebook, } \\
\text { Instagram and Snapchat }\end{array}$ \\
\hline 4 & Arents et al, 2021, Netherlands ${ }^{12}$ & Quasi-experimental design & $360^{\circ}$ virtual reality video \\
\hline 5 & Boatin et al, 2015, Uganda and USA ${ }^{13}$ & Experimental design & Teleconference Program \\
\hline 6 & Lee $\mathrm{K}$ et al, 2021 , data no available ${ }^{14}$ & $\begin{array}{l}\text { Content analysis and quality } \\
\text { evaluation }\end{array}$ & Cesarean Delivery-Related Videos on YouTube \\
\hline 7 & Foglia et al, 2020, data no available 15 & $\begin{array}{l}\text { Prospective educational } \\
\text { intervention }\end{array}$ & $\begin{array}{l}\text { Didactic learning and practice evaluated with a } \\
\text { high fidelity simulator }\end{array}$ \\
\hline
\end{tabular}

\section{Discussion}

The 2019 novel coronavirus disease pandemic has challenged the structure and delivery of undergraduate medical education and specialist medical education. Face-toface clinical experiences are difficult to replicate virtually, and missed experiences present a training challenge for those preparing to join the healthcare workforce. Challenges to medical education during the 2019 coronavirus disease era include engagement via video conferencing and social media platforms, work-life balance, and increasing concerns about provider burnout. 16 
Various kinds of media can be developed in the learning and teaching process during the pandemic, especially to resident doctors in the focus of obstetrics and gynecology. Media has a significant contribution in supporting the learning process. In the midst of this COVID-19 crisis, it is very important for the academic community to learn from experience and prioritize forward-thinking and scientific approaches as practical solutions to implement. In the use of media, not all studies describe patient involvement in the study. Patients do need to be involved with a note that ethically and medical records may need to be given rules so that patient confidentiality is not easily identified for educational reasons. Media innovation is focused on serving and having a positive effect as educators for peers, patients, and their communities, using tools available through social media and other modalities to help influence behavior in positive ways. The COVID-19 pandemic could represent a lasting transformation in medicine with advances in telehealth, adaptive research protocols, and clinical trials with flexible approaches to achieving solutions. ${ }^{17}$ With the advancement of technology and social media, distance learning is a new and rapidly developing approach and may be the optimal solution to sustain the learning process in extraordinary and emergency situations such as the COVID-19 pandemic. ${ }^{18}$

The development of simulation models seems to be a promising field in surgical learning. Simulation, in all of its incarnations, is a wonderful tool for health care educators, enabling students to achieve this goal without putting the patient in danger. ${ }^{19}$ The purpose of the simulation is to realistically replicate patient care scenarios for feedback and assessment purposes. If done correctly, simulation will create a purposeful educational environment because learning activities are predictable, consistent, standardized, safe, and can be produced more. This environment encourages learning through experimentation and trial and error with opportunities to retrain and practice without harming the patient. This does not mean that simulation can replace actual clinical experience, however, the ideal is not always practical. ${ }^{20}$ Professional qualities include management responsibilities, assessment and development of practice, can work well together, behave and carry out ethics, sincerity in providing what is best for patients and health advocacy. Currently, various educational institutions have used technology as an alternative media compared to face to face. As for the education of specialist doctors to overcome the gap in competence and skills, telemedicine can be carried out, and the use of simulators and video procedures for an action.

\section{Conclusion}

The challenges experienced in medical resident education, especially the focus on obstetrics and gynecology during the COVID-19 pandemic, have become a consideration for the need for innovative media so that learning can run as usual. All aspects need to ensure quality education for resident doctors because they will continue to provide health services in the future. Further research on the use of innovative media needs to be done such as research on C-Section simulations and interactive videos.

\section{References}

1. Kemenkes. Status wabah corona di indonesia ditetapkan sebagai bencana nasional [Internet]. 2020. Available from: https://www.kemkes.go.id/article/view/20031500003/statuswabah-corona-di-indonesia-ditetapkan-sebagai-bencananasional.html. [Online]

2. Osman, M. E. Global Impact of COVID-19 on Education Systems: The emergency eemote eeaching at sultan qaboos university. J
Educ Teach. 2020; 1-10. https://doi.org/10.1080/02607476.2020.1802583

3. Suryahadi, A. The impact of covid-19 outbreak on poverty: an estimation for Indonesia. Smeru Work Pap Aoril. 2020; I(1):11. https://doi.org/10.1080/00074918.2020.1779390

4. Firman, F, Rahayu, S. Pembelajaran online di tengah pandemi Covid- 19. Indones J Educ Sci. 2020; 1(2):81-9. https://doi.org/10.31605/ijes.v2i2.659

5. Wiknjosastro H. Ilmu Bedah kebidanan. Jakarta: Yayasan Bina Pustaka Sarwono Prawirohardjo; 1994.

6. Sihombing, N., Saptarini, I. \& Putri, D. S. K. Determinan persalinan seksio sesarea di Indonesia (Analisis Lanjut Data Riskesdas 2013). J Kesehat Reproduksi. 2017; 8(1):63-75. https://doi.org/10.22435/kespro.v7i1.5096.15-24

7. Tolu L, Feyisa G, Ezeh A. Managing resident workforce and residency training during covid-19 pandemic: Scoping Review of Adaptive Approaches. , 10 Aug, 11(527), p. 535. Adv Med Educ Pr. 2020; 11(527):535. https://doi.org/10.2147/AMEP.S262369

8. Bitonti G, Palumbo R, Galo C, Erika R. Being an obstetrics and gynaecology resident during the COVID-19: Impact of the pandemic on the residency training program. Eur J Obs Gynecol Reprod Biol. 2020; 32771888(48):51. https://doi.org/10.1016/j.ejogrb.2020.07.057

9. Fitri ADWI, Natasha N, Shafira AYU, Puspasari A, Tarawifa S. The Development of the Basic Obstetric Ultrasound Learning Media for Undergraduate Medical Students. 2020; 4(1):263-72.

10. Kim K, Lee B, Park Y, Jung EY, Kim SK, Suh DH, et al. Factors encouraging mobile instant messaging service use in medical education. Peer] [Internet]. 2019 Jul 8; 7:e7275-e7275. Available from: https://pubmed.ncbi.nlm.nih.gov/31328039 https://doi.org/10.7717/peerj.7275

11. Stalcup AM, Pak A, Dotters-Katz S, Gray B. Social Media Use, Beliefs, and Training Among Residents and Medical Students in Ob/Gyn [110]. Obstet Gynecol [Internet]. 2018;131. Available from:

https://journals.lww.com/greenjournal/Fulltext/2018/05001/ Social Media Use, Beliefs, and Training Among.577.aspx https://doi.org/10.1097/01.AOG.0000533147.30352.89

12. Arents V, de Groot PCM, Struben VMD, van Stralen KJ. Use of $360^{\circ}$ virtual reality video in medical obstetrical education: a quasiexperimental design. BMC Med Educ [Internet]. 2021; 21(1):202. https://doi.org/10.1186/s12909-021-02628-5

13. Boatin A, Ngonzi J, Bradford L, Wylie B, Goodman A. Teaching by Teleconference: A Model for Distance Medical Education across Two Continents. Open J Obstet Gynecol [Internet]. 2015/11/18. 2015 Nov; 5(13):754-61. Available from: https://pubmed.ncbi.nlm.nih.gov/27239388 https://doi.org/10.4236/ojog.2015.513106

14. Lee K, Joo Y, Choi S, Park S, Lee K, Kim Y SG. Content Analysis and Quality Evaluation of Cesarean Delivery- Related Videos on YouTube: Cross-sectional Study. J Med Internet Res. 2021; 23(7):e24994. https://doi.org/10.2196/24994

15. Foglia LM, Eubanks AA, Peterson LC, Hickey K, Hammons CB, Borgia LB, et al. Creation and Evaluation of a Cesarean Section Simulator Training Program for Novice Obstetric Surgeons. Cureus [Internet]. 2020 Sep 9; 12(9):e10324-e10324. Available from: https://pubmed.ncbi.nlm.nih.gov/33052285

16. Hilburg R, Patel N, Ambruso S, Biewald MA, Farouk SS. Medical Education During the Coronavirus Disease-2019 Pandemic: Learning From a Distance. Adv Chronic Kidney Dis [Internet]. 2020/06/23. 2020 Sep; 27(5):412-7. Available from: https://pubmed.ncbi.nlm.nih.gov/33308507 https://doi.org/10.1053/j.ackd.2020.05.017

17. Rose S. Medical Student Education in the Time of COVID-19. JAMA [Internet]. 2020 Jun 2; 323(21):2131-2. https://doi.org/10.1001/jama.2020.5227

18. Al-Balas M, Al-Balas HI, Jaber HM, Obeidat K, Al-Balas H, Aborajooh EA, et al. Distance learning in clinical medical education amid COVID-19 pandemic in Jordan: current situation, challenges, and perspectives. BMC Med Educ [Internet]. 2020 20(1):341. https://doi.org/10.1186/s12909-020-02257-4

19. Fanning RM, G. D. The role of debriefing in simulation-based learning. Simul Heal. 2007; 2(115-25):2. https://doi.org/10.1097/SIH.0b013e3180315539

20. Okuda Y, Byrson E, De Maria S, Jacobson. The utility of simulation in medical education: what is the evidence? Mt Sinai J Med. 2009; 4(330):43. https://doi.org/10.1002/msj.20127 